\title{
PENILAIAN OBYEK WISATA DAN KARAKTERISTIK PENGUNJUNG PANTAI AIR MATA PERMAI DESA SUNGAI AWAN KECAMATAN MUARA PAWAN KABUPATEN KETAPANG
}

\author{
(Assessment Of Tourism Objects And Characteristic Air Mata Permai Beach At Sungai Awan \\ Village Muara Pawan District Of Ketapang Regency)
}

\author{
Yulinda Batara, Slamet Rifanjani \\ Fakultas Kehutanan Universitas Tanjungpura, Jalan Imam Bonjol Pontianak, 78124 \\ Email : julinda.batara@gmail.com
}

\begin{abstract}
One of the natural attractions in Ketapang Regency is Air Mata Permai Beach. This Tourism Object has natural attractions such as coastal scenery, sunset beauty, and others. The purpose of this study is to provide an assessment of the tourism objects and characteristics of visitors to Air Mata Permai Beach in Sungai Awan Village, Ketapang Regency. Research from May to June 2018, the research method uses a survey method by giving questionnaires or questionnaires as instruments to respondents by accidental sampling. The results of the study show that the assessment of potential objects includes the assessment of attractiveness, accessibility, accommodation obtains value (A) for the assessment of criteria for the conditions of the socio-economic environment and the assessment of supporting facilities and infrastructure gets a value $(B)$. While the value for potential development of tourism object in Air Mata Permai Beach in Sungai Awan Village, Muara Pawan District, Ketapang Regency is $2,486.8$ and the average value is 497.36 or value $(A)$, which is potential to be developed. The characteristics of visitors Air Mata Permai Beach, which includes female sex, dominate around $53.30 \%$, with the age of visitors who frequently visit an average of 13-22 years and the origin of visitors who dominate comes from Sungai Awan Village with a presentation of $26.68 \%$ because the location is close to the beach location.
\end{abstract}

Keywords: , Assessment of Air Mata Permai Beach Objects, Characteristics of visitors

\section{PENDAHULUAN}

Ketapang merupakan salah satu Kabupaten yang berada di Provinsi Kalimantan Barat, yang memiliki beberapa obyek wisata pantai, antara lain, Pulau Sawi, Pulau Cempedak, Pulau Sempadi, Pantai Tanjung Batu, Pantai Sungai Kinjil, Pantai Air Mata Permai. Menurut Dinas Pariwisata Ketapang (2017), Pantai Air Mata Permai menjadi salah satu tempat yang menarik untuk dikunjungi karena adanya pesisir pantai yang memanjang, keberadaan ekosistem pantai (flora dan fauna), hutan bakau (Mangrove) dan pemandangan matahari terbenam. Kegiatan wisata yang dapat dilakukan seperti olahraga pantai (volly pantai, bersepeda, atv, dan jogging) serta dapat dilakukan kegiatan perkemahan, permainan dan pengamatan burung. Tujuan dari penelitian ini adalah memberikan penilaian terhadap obyek wisata dan karakteristik pengunjung Pantai Air Mata Permai di Desa Sungai Awan Kabupaten Ketapang. Manfaat dari penelitian adalah untuk memberikan informasi berupa penilaian 
obyek wisata dan karakteristik pengunjung yang berguna untuk pengembangan ke dapan. Menurut Yoeti (2008) dalam Nurdianti (2013), tujuan pengembangan ekowisata (wisata alam) yang sebenarnya yaitu usaha mengkonservasi suatu kawasan dengan memperhatikan kesejahteraan dan mempertahankan kelestarian lingkungan hidup itu sendiri. Daya tarik wisata menurut Kodhyat (1996) adalah segala sesuatu yang mendorong orang untuk berkunjung dan singgah di daerah tujuan wisata yang bersangkutan.

\section{METODE PENELITIAN}

Penelitian ini dilaksanakan pada Obyek Wisata Pantai Air Mata Permai yang berada di Desa Sungai Awan Kanan Kecamatan Muara Pawan Kabupaten Ketapang. Waktu penelitian dilaksanakan selama \pm 3 minggu dari bulan Mei sampai dengan bulan Juni tahun 2018. Potensi ODTWA wisata pantai didapatkan dari hasil wawancara terhadap pengunjung Pantai Air Mata Permai dengan mengunakan kuesioner terstruktur yang dibuat oleh peneliti sesuai acuan pedoman penilaian ODTWA PHKA 2003. Jumlah responden yang diambil seperti pada umumnya yang diperlukan dalam penelitian korelasional yaitu jumlah sampel minimal untuk memperoleh hasil data yang baik adalah 30 responden. Data yang di kumpulkan mengacu pada pedoman penilaian obyek dan daya tarik wisata alam. Kriteria-kriteria setiap penilaian Obyek dan Daya Tarik Wisata Alam secara ringkas dapat dilihat pada tebel berikut :

Tabel 1. Kriteria Penilaian Daya Tarik Wisata ( Assessment Criteria of Tourism Potency

\begin{tabular}{llc}
\hline No & Kriteria & Bobot \\
\hline 1 & Daya Tarik & 6 \\
2 & Aksebilitas & 5 \\
3 & Kondisi lingkungan sosial ekonomi & 5 \\
4 & Akomodasi & 3 \\
5 & Prasarana dan sarana penunjang & 2 \\
\hline
\end{tabular}
Jumlah nilai

$\overline{\text { Sumber : Modifikasi Buku Biru Sasaran Ukuran Pembinaan Pengembangan Obyek Wisata Pantai PHKA }}$ Tahun 2003

Teknik pengambilan data meggunakan teknik accidental sampling dan purposive sampling. Teknik accidental sampling digunakan kepada responden pengunjung untuk menilai unsur/kriteria daya tarik. Sedangkan kritria yang lsin menggunakan teknik purposive sampling kepada indifidu ataupun instansi yang terkait dengan dengan kriteria-kriteria tersebut.

Pengolahan data mengenai potensi ODTW menggunakan metode skoring, diolah dengan menggunakan Pedoman Analisis Daerah Operasi Objek dan Daya Tarik Wisata Alam (ADOODTW) Direktorat Jenderal PHKA tahun 2003 yang telah dimodifikasi sesuai dengan nilai/skor yang telah ditentukan untuk masing-masing kriteria. Jumlah nilai untuk satu kriteria 
penilaian ODTWA dapat dihitung dengan persamaan sebagai berikut :

$\mathbf{S}=\mathbf{N} \times \mathbf{B}$

Keterangan:

$\mathrm{S}=$ skor/nilai suatu kriteria

$\mathrm{N}=$ jumlah nilai-nilai unsur pada kritera

$\mathrm{B}=$ bobot nilai

Hasil dari nilai yang telah di dapat dibandingkan lagi dengan nilai klasifikasi pengembangan dari masing- masing kriteria penilaian, setelah itu nilai bobot yang telah didapat dari tabulasi klasifikasi pengembangan dari masing-masing kriteria penilaian tersebut dirata-ratakan berdasarkan kelas baik, sedang dan buruk untuk mendapatkan hasil akhir penilaian obyek wisata Pantai Air Mata Permai yang dapat dilihat pada tebel 2 berikut ini :

Tabel 2. Klasifikasi Unsur Pengembangan Berdasarkan Nilai Bobot Setiap Kriteria Penilaian ( Classification of Development Point Based on Weight Value of Assessment Criteria )

\begin{tabular}{lcl}
\hline No & Nilai Total & Penilaian Potensi Unsur \\
\hline 1 & $\geq 2.235-2.850$ & Potensial Dikembangkan (A) \\
2 & $\geq 1.675-2.235$ & Cukup Potensial Dikembangkan (B) \\
3 & $950-1.675$ & Tidak Potensial Dikembangkan (C) \\
\hline
\end{tabular}

Sumber: Modifikasi Buku Biru Sasaran Ukuran Pembinaan Pengembangan Obyek Wisata Pantai PHKA Tahun 2003

HASIL DAN PEMBAHASAN

A. Penilaian Objek Daya Tarik Wisata

Pantai Air Mata Permai

Daya tarik wisata adalah segala hal dalam keadaan baik yang nyata dan tidak didapat diraba, digarap, diatur, dan di sediakan sedemikian rupa sehingga dapat bermanfaat atau dimanfaatkan, diwujudkan sebagai kemampuan faktor dan unsur yang diperlukan atau menentukan pengembangan kepariwisataan, baik itu berupa suasana, kejadian, benda maupun layanan atau jasajasa. (Darmardjati, 2015). Hasil perhitungan setiap unsur dan sub unsur pada kriteria penilaian Objek Daya Tarik Wisata Pantai Air Mata Permai yang berpedoman pada Objek dan Daya Tarik Wisata Alam PHKA 2003 secara ringkas dapat di lihat pada tabel 3.

Tabel 3. Rekapitulasi Penilaian Obyek Wisata Pantai Air Mata Permai di Desa Sungai Awan Kecamatan Muara Pawan Kabupaten Ketapang (Recapitulalion of assessments of sxenic shore tourism objects in the Sungai Awan village of Muara Pawan district in Ketapang Regency)

\begin{tabular}{lllll}
\hline No & Kriteria & Nilai & Bobot & Jumlah Nilai \\
\hline 1 & Daya Tarik & 125,3 & 6 & 751,8 \\
2 & Aksebilitas & 110 & 5 & 550 \\
3 & Kondisi lingkungan sosial ekonomi & 195 & 5 & 975 \\
4 & Akomodasi & 30 & 3 & 90 \\
5 & Prasarana dan sarana penunjang & 60 & 2 & 120 \\
\hline
\end{tabular}


Berdasarkan tabel diatas dapat diketahui bahwa hasil penelitian untuk unsur penelitian kriteria Obyek Daya Tarik Wisata mendapat jumlah nilai total sebesar 125,3

Nilai yang telah di dapat dikalikan dengan nilai bobot untuk kriteria penilaian daya tarik wisata yaitu 6. Nilai kriteria penilaian daya tarik obyek wisata pantai dengan nilai keseluruhan 125,3 × $6=751,8$. Nilai yang telah di dapat dikelaskan dengan klasifikasi Obyek Wisata Pantai Air Mata Permai memiliki Daya Tarik yang bernilai (A) yang berarti baik untuk menjadi obyek wisata alam. Kondisi Pantai Air Mata Permai memiliki beberapa unsur berupa keindahan yang meliputi variasi pemandangn pulau/gunung di lautan, keindahan pantai, keserasian pemandangan pantai dan sekitarnya serta bisa melihat tumbuhan akasia yang tersusun rapi dengan gazebbo untuk bersantai. Keselamatan/kecaman pantai juga sangat di perhatikan saat melakukan rekreasi adalah satunya yang harus diperhatikan tidak adanya arus balik berbahaya pada saat pengunjung bersantai dan menikmati ombak dipantai dengan tenang, Suasana pasir yang terdapat di pantai berwarna putih yang disebabkan oleh batuan yang ada didaerah pantai berasal dari batuan kapur batu karang yang hancur serta jauh dari muara sungai. Variasi kegiatan yang ada di Pantai Air Mata Permai sengat banyak yaitu ada permainan ATV, kanno, bersampan, berolahraga voli dan menikmati sunset. Sebagai lokasi wisata pantai kebersihan sangat menjadi perhatian karena tidak ada pengaruh pelabuhan, tempat pelelangan ikan/pabrik/pasar,sampah.

Hasil penjumlahan keseluruhan untuk kriteria aksesibilitas di Pantai Air Mata Permai yaitu 110 x $5=550$ dimana kondisi dan jarak jalan darat menuju pantai hanya $17 \mathrm{~km}$ dengan waktu tempuh 1 jam dengan jumlah nilai total 110 dikalikan nilai bobot 5 . Hasil penjumlahan keseluruhan untuk kriteria aksesibilitas di Obyek Wisata merupakan faktor yang mempermudah pengunjung untuk berpergian dari tempat tinggal pengunjung ke lokasi tempat wisata yang akan dikunjunginya maka dari hasil tersebut menunjukan bahwa kawasan Pantai Air Mata Permai mendapatkan nilai (A) yaitu baik untuk menjadi obyek wisata alam.

Berdasarkan hasil pengamatan langsung dan wawancara secara purposif kepada instansi terkait terhadap kriteria penilaian kondisi sosial ekonomi Kecamatan Muara Pawan dengan melihat faktor tata ruang wilayah obyek, status lahan, tingkat penganguran, mata pencarian penduduk, ruang gerak pengunjung, pendidikan, tingkat kesuburan tanah, persepsi masyarakat terhadap objek wisata alam. Nilai 195 merupakan jumlah dari nilai total kondisi lingkungan sosial ekonomi maka hasil nilai rata-rata skor kondisi lingkungan sosial ekonomi dikalikan dengan nilai bobot yaitu 5 jadi di dapatkan hasil 195 × $5=975$, kriteria kondisi dinyatakan nilainya (B) yaitu sedang untuk menjadi obyek wisata alam 
Penilaian Kriteria Akomodasi memperoleh nilai sebesar 30. Hasil tersebut dikarenakan jumlah kamar yang tersedia dalam radius $15 \mathrm{~km}$ dari obyek wisata pantai adalah >100 kamar. Nilai ini dikalikan bobot yaitu $30 \times 3=$ 90 Jadi Kriteria akomodasi dinyatakan dengan baik untuk menjadi obyek wisata alam (A).

Penilaian kriteria sarana dan prasarana penunjang memperoleh nilai 60. Hasil tersebut di dapat dari penilaian sarana sebesar 30, di karenakan sarana yang terdapat dalam radius $20 \mathrm{~km}>4$ jenis yaitu terdiri dari rumah makan/minum, pusat perbelanjaan, bank, toko cendramata, tempat peribadatan dan toilet umum. Di samping itu nilai prasarana pengunjung memperoleh nilai 30 juga, dikarenakan prasarana pengunjung yang terdapat dalam radius $20 \mathrm{~km}>4$ yaitu meliputi kantor pos, puskesmas/klinik, warnet dan jaringan radio. Maka nilai total menjadi $30+30=60$ jadi $60 \times 2$ (bobot) $=120$, yang berarti nilai sarana dan prasarana sedang untuk menjadi obyek wisata pantai (B). Hasil penilaian keseluruhan terhadap kriteria-kriteria Obyek Wisata Pantai Air Mata Permai dapat di lihat pada tebel 4 .

Tabel 4. Hasil Setiap Penilaian Berdasarkan Standar Baku Klasifikasi Pengembangan ODTWA PHKA 2003 ( Results of Criteria Assessment Based on Depelopment Classification Standards ODTW PHKA 2003)

\begin{tabular}{llll}
\hline No & Kriteria & Nilai & Klasifikasi \\
\hline 1 & Daya Tarik & 751,8 & Baik (A) \\
2 & Aksebilitas & 550 & Baik (A) \\
3 & Kondisi lingkungan sosial ekonomi & 975 & Sedang (B) \\
4 & Akomodasi & 90 & Baik (A) \\
5 & Prasarana dan sarana penunjang & 120 & Sedang (B) \\
& & $2.486,8 / 5$ & (A) Potensial \\
& \multirow{2}{*}{ Skor Total Penilaian /5 } & $=497.36$ & Dikembangkan \\
& & & sebagai Obyek \\
& & & Wisata Alam
\end{tabular}

Hasil perhitungan pada tebel diatas diketahui bahwa Pantai Air Mata Permai mendapat nilai (A) yang berarti baik untuk menjadi sebagai salah satu tujuan obyek wisata yang ada di Kabupaten Ketapang dengan skor total penilaian 2.486,8 : $5=$ 497.36. Berdasarkan hasil penelitian di Pantai Air Mata Permai memiliki potensi daya tarik kawasan yang potensial dikembangkan (A) sebagai tempat tujuan wisata alam. Kondisi kawasan pantai memiliki keunikan, kepekaan sumberdaya alam, mempunyai pilihan/variasi kegiatan wisata alam, yang menonjol seperti permainan, pemandangan sunset, keselamatan/ kecaman pantai, pasir, dan kebersihan. Daya tarik suatu lokasi kawasan wisata merupakan alasan yang utama para pengunjung untuk mengunjungi ke lokasi wisata dalam rangka melakukan kegiatan wisata. Sudarto (1999), menyatakan unsur-unsur 
paling penting yang menjadi daya tarik sebuah daerah tujuan wisata/ ekowisata adalah kondisi alamnya, kondisi flora dan fauna yang unik, langka dan endemik, kondisi fenomena alamnya, kondisi adat dan budayanya.

Menurut Shayadat (2006), agar objek daya tarik wisata dapat dikembangkan sebagai ODTWA diperlukan berbagai upaya seperti promosi dan pemasaran guna menarik potensi pasar, meningkatkan pengelolaan dan pelayanan sesuai standar pelayanan, melakukan pemenuhan terhadap standar akomodasi yang diperlukan dan meningkatkan diversifikasi atraksi wisata. Menurut Cooper et al(1998), beberapa komponen objek wisata yaitu atraksi wisata baik berupa alam, buatan (hasil karya manusia), atau peristiwa (kegiatan) yang merupakan alasan utama kunjungan. Fasilitas-fasilitas dan pelayanan dibutuhkan oleh wisatawan di daerah tujuan wisata. Akomodasi, makanan dan minuman tidak hanya tersedia dalam bentuk fisik tapi juga harus dapat menciptakan perasaan hangat dan memberikan kenangan pada lingkungan dan makanan setempat. Aksesibilitas (jalan dan transportasi) merupakan salah satu faktor kesuksesan daerah tujuan wisata. Faktor-faktor pendukung seperti kegiatan pemasaran, pengembangan, dankoordinasi juga diperlukan.

\section{B. Karakteristik Pengunjung Kawasan Wisata Pantai Air Mata Permai}

Secara gender pengunjung yang sering datang di daerah obyek wisata Pantai Air Mata Permai 53,30\% pengunjung perempuan. Hal ini dikarenakan pemandangan alam di senja hari yang di tawarkan oleh ODTWA sangat romantis dan disenangi wisatawan perempuan sebagian besar pengunjung perempuan ini sangat menikmati sunset sembari berswa foto. Presentasi nya dapat dilihat pada diagram berikut :

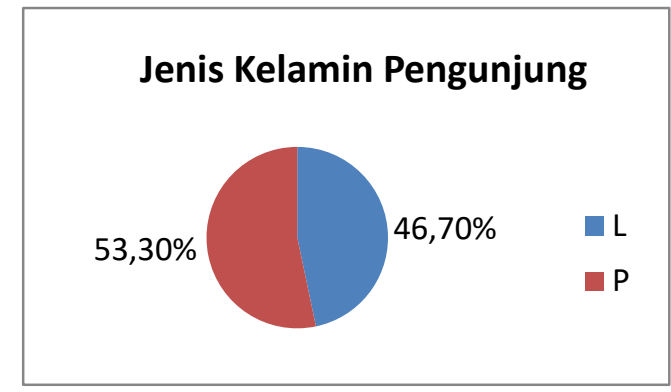

Gambar 1. Jenis Kelamin Pengunjung (Visitor Gender)

Sebagian besar pengunjung yang datang ke obyek wisata Pantai Air Mata Permai berusia 13 tahun sampai 22 tahun, karena mereka memiliki waktu luang yang lebih banyak. Kelompok usia ini senang melakukan aktifitas bersama kelompoknya dan sebagian sudah mulai memiliki ketertarikan terhadap lawan jenis dan menjadikan ODTWA sebagai media pendekatan dengan pasangan mereka. 


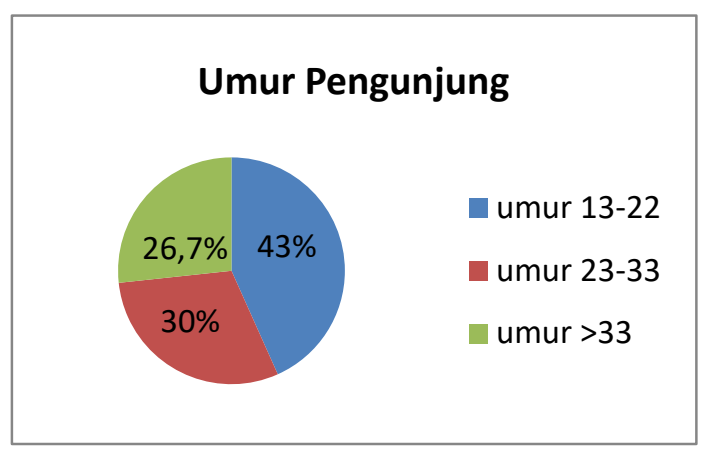

Gambar 2. Umur Pengunjung (Visitor Age)

Daerah asal pengunjung yang Desa Sungai Awan yaitu 26,68\%. Hal berwisata ke Pantai Air Mata Permai ini karena wilayah tersebut jaraknya berdasarkan hasil wawancara yang telah dilakukan cukup bervariasi namun paling dekat dengan objek wisata Pantai pengunjung yang paling sering datang ialah pengunjung yang berasal dari Air Mata Permai . Diagram asal pengunjung dapat dilihat sebagai berikut :

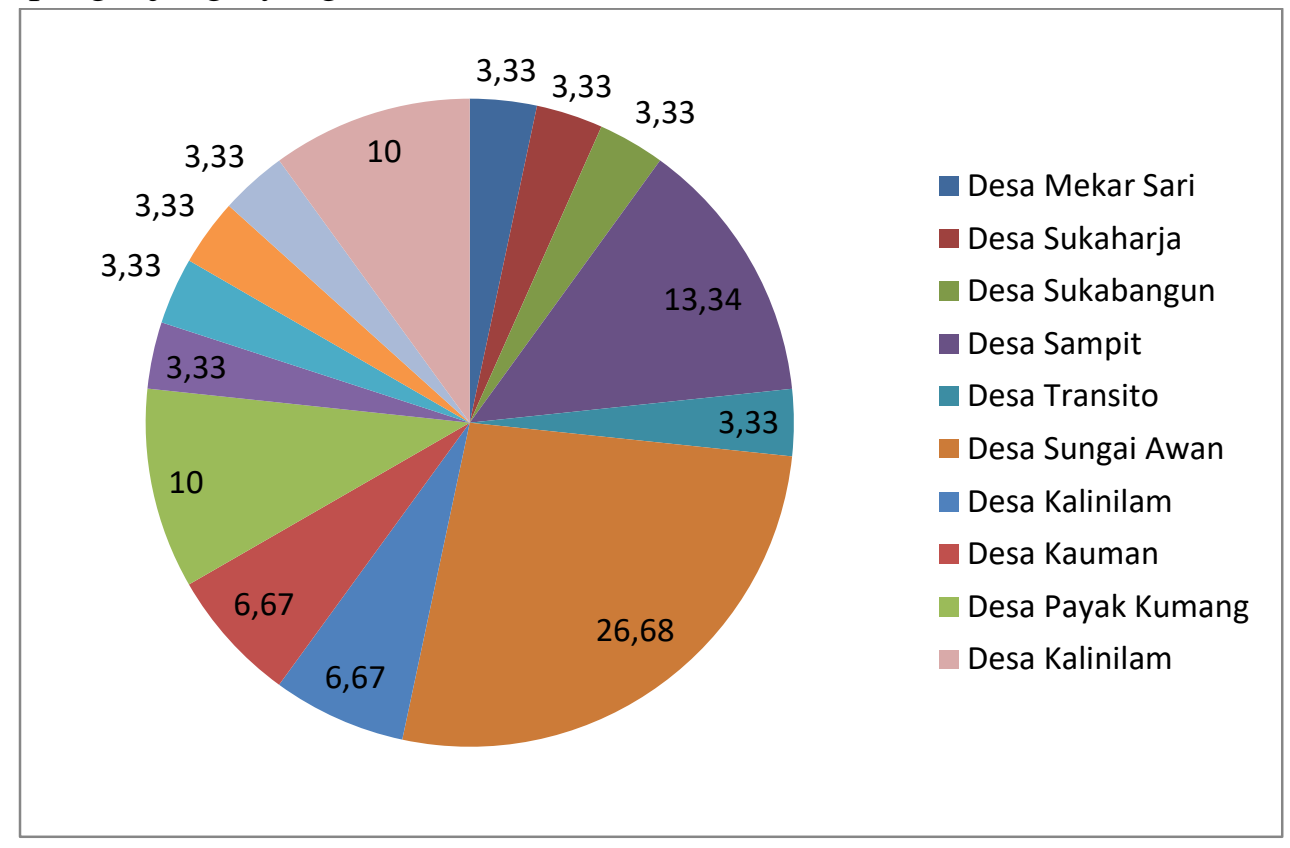

Gambar 3. Asal Pengunjung (Origin of Visitor)

\section{Kesimpulan}

1. Nilai Potensi Obyek Wisata Pantai Air Mata Permai di Desa Sungai Awan Kecamatan Muara Pawan Kabupaten Ketapang sebesar 2486,8 dan nilai rata-rata 497,36 mendapatkan nilai (A) pontensial untuk dikembangkan.
2. Sebagai obyek wisata alam, wisatawan yang berkunjung ke ODTWA Pantai Air Mata Permai didominasi oleh pengunjung perempuan, secara usia antara 13-22 tahun dan asal pengunjung sebagian besar berasal dari Desa Sungai Awan. 


\section{Saran}

Karakteristik pengunjung yang dominan yaitu perempuan dengan usia muda, maka pihak pengelola disarankan mengakomodir kebutuhan pengunjung tersebut seperti menambah tempat spotspot fotografi/ swafoto dan memperbanyak permainan outdor. Pihak pengelola, masyarakat setempat, Pemerintah, dan Instansi terkait dapat bekerja sama dalam pengelolaan Obyek Wisata Pantai Air Mata Permai serta mempertahankan dan menjaga kelestarian potensi sumber daya alam yang ada di kawasan wisata Pantai Air Mata Permai.

\section{DAFTAR PUSTAKA}

Cooper, C., J, Fletcher. D., Gilbert, S., Wanhill., R. Shepherd., 1998. Editor. Tourism: Priciples and Practic.Ed ke2. Pearson Education Limited. England

[DPKKK] Dinas Pariwisata dan Kebudayaan Kabupaten Ketapang. 2017. Pesona Wisata Kabupaten Ketapang Kalimantan Barat. Pantai Air Mata Permai.
Damardjati. S. R 2015. Istilah- istilah Dunia Pariwisata. Jakarta : Pradnya Paramita

Nurdianti, A.2013. Potensi Pengembangan Wisata Alam Di Habitat Maleo (Macrocephalon maleo) Taman Nasional Lore Lindu Bidang Pengelolaan Wilayah (BPW) I Saluki Kec. Gumbasa Kab. Sigi.Warta Rimba. I (1) : $1-8$

[PHKA] Perlindungan Hutan dan Konservasi, a. Pedoman Analisis Pedoman Daerah Operasi Obyek dan Daya Tarik Wisata Alam. 2003. Bogor : Direktorat Jendral Perlindungan Hutan dan Konservasi Alam

Sudarto, G. 1999. Ekowisata: Wahana Pelestarian Alam, Pengembangan Ekonomi Berkelanjutan, dan Pemberdayaan Masyarakat. Yayasan Kalpataru Bahari. Bekasi.

Syahadat E. 2006. Faktor-Faktor yang Mempengaruhi Kunjungan Wisatawan di Taman Nasional Gunung Gede Pangrango (TNGP). Jurnal Penelitian dan Sosial Ekonomi Kehutanan 3(1): $1-16$. 